Bangladesh Journal of Neuroscience 2014; Vol. 30 (1) : 35-44

\title{
Association of Dementia in Ischemic Stroke: A Case Control Study
}

\author{
DR. ABU JAFOR MD SALAHUDDIN¹, MD REZAUL KARIM KHAN², MD MUNIRUZZAMAN BHUIYAN², \\ NURUDDIN MD EUSUF ${ }^{3}$, RASED IMAM ZAHID ${ }^{4}$, KHAIRUL KABIR PATWARY $^{5}$, \\ MUHAMMAD SALAHUDDIN ${ }^{6}$, MD SAYEED HASSAN ${ }^{1}$, MD ABDULALIM $^{4}$, \\ SUKUMAR MAJUMDER ${ }^{7}$, MD MASUD RANA $^{8}$
}

\begin{abstract}
:
Objectives: To evaluate the association of dementia in ischemic stroke. Methodology: This case control study was carried out in the department of Neurology at BSMMU, Dhaka from 1st January 2010 to 31st December 2011 for duration of two years to evaluate the association of dementia in ischemic stroke. The target population for this study include all patients presented with ischemic stroke at the range of 3 to 6 months after stroke with the age group of 40 to 70 years are included in this study and patients of dementia other than ischemic stroke like Alzhiemer's disease, vit-B12 deficiency, thyroid dysfunction were excluded from this study. A total number of 120 respondents were included in this study. Age \& sex matched 60 patients of ischemic stroke were selected as cases and rest 60 people were taken as control group. Informed written consent was taken from each patient or his/ her attendant. All information regarding history and physical findings; and other risk factors for dementia were collected to fill up the preformed questionnaire. Relevant physical examinations like nervous system examination, selected general and systemic examination were recorded. Result \& Observation: Dementia was present in case and control group 18(30.0\%) and 2(3.3\%) respectively. The difference was statistically significant $(p=0.001)$. Present smoking habit was more in case (45.0\%) than in control group (16.7\%) which was statistically significant ( $p=0.001)$ with a OR of 4.07 with a $95 \% \mathrm{Cl}$ of 1.89-8.75. Past smoking habit was more in case (16.7\%) than control group (11.7\%). Non-smoker was more in control (71.7\%) than case group (38.3\%). Diabetes mellitus was more common in case group (38.3\%) than control group 5(8.3\%) which was statistically significant $(p=0.001)$ with a $6.84 \mathrm{OR}$ and $95 \% \mathrm{Cl}$ of 2.39-19.6. Conclusion: The study permit to conclude that dementia is directly associated with ischemic stroke. We found a correlation between age, family history of dementia, hypertension, diabetes mellitus and dyslipidemia with dementia.
\end{abstract}

Keywords: Dementia, Ischemic Stroke.

Introduction:

Dementia is an acquired and persistent compromise in multiple cognitive domains that is severe enough to interfere with everyday functioning ${ }^{1}$. This definition stands in contrast with delirium or acute confusional state, which are distinguished primarily by prominent deficits or fluctuations in attentional processing. Although dementia syndromes tend to be chronic, progressive, and irreversible, and acute confusional states tend to be acute to subacute, fluctuating,

1. Junior Consultant, National Institute of Neurosciences \& Hospital, Dhaka.

2. Professor,Department of Neurology, Bangabandhu Sheikh Mujib Medical University, Dhaka, Bangladesh

3. Thana Health \& Family Planning Officer, Moralganj Health Complex, Bagerhat.

4. Medical officer, National Institute of Neurosciences \& Hospital, Dhaka.

5. Assistant professor, National Institute of Neurosciences \& Hospital, Dhaka.

6. Registrar, Department of Medicine, Chittagong Medical College Hospital,

7. Registrar, Department of Neurology, Rangpur Medical College Hospital, Rangpur.

8. MO, Department of Neurology, Bangabandhu Sheikh Mujib Medical University, Dhaka, Bangladesh. 
and reversible, these distinctions are more relative than absolute ${ }^{2}$.

Dementia is a syndrome consisting of a loss of several separable but overlapping intellectual abilities and present in a number of different combinations ${ }^{3}$. Memory is the most common cognitive ability lost with dementia; $10 \%$ of persons $>70$ and $20-40 \%$ of individuals $>85$ years of age have clinically identifiable memory loss. In addition to memory, other mental faculties are also affected in dementia; these include language, visuospatial ability, calculation, judgment, and problem solving. Neuropsychiatric and social deficits also develop in many dementia syndromes, resulting in depression, withdrawal, hallucinations, delusions, agitation, insomnia, and disinhibition. The most common forms of dementia are progressive, but some are static and unchanging or fluctuate dramatically from day to day. Most diagnoses of dementia require some sort of memory deficit, although there are many dementias, such as frontotemporal dementia, where memory loss is not a presenting feature ${ }^{4}$.

Dementia affects more than 4 million Americans and results in a total health care cost of $>\$ 100$ billion annually. The reported frequency of dementia due to potentially reversible causes varies from 0 to $23 \% 5,6,7$. Historically, patients with dementia due to recurrent strokes were diagnosed with multiinfarct dementia termed as vascular dementia, since the disease can occur after a single vascular incident ${ }^{8}$. Vascular dementia is widely accepted as the second most common cause of cognitive impairment.

Stroke is clearly related to vascular dementia, the second-most-common type of dementia ${ }^{9}$. There has been a recent upsurge of interest in poststroke dementia (PSD), which is a subtype of vascular dementia. PSD is operationally defined as the presence of dementia identified at 3 months after an acute, either recurrent or first-ever, stroke ${ }^{10}$. The prevalence of PSD among recurrent or first-ever stroke patients varies from $6 \%$ to $31.8 \%{ }^{10-12}$.

Stroke is the major cause of physical disability in adults ${ }^{13}$. It is the second most common cause of dementia, and the third leading cause of death in developed countries ${ }^{14}$. In a population of 1 million inhabitants, 2400 patients will have a stroke every year, of whom fewer than $50 \%$ will be independent 1 year later ${ }^{15}$. Leys et al $(2005)^{13}$ reported that dementia is one of the major causes of dependency after stroke.

Poststroke dementia (PSD) is one of the main causes of dependency in survivors and includes any dementia after a stroke, irrespective of its cause like vascular, degenerative, or mixed ${ }^{13}$. A huge increase in prevalence and burden of PSD is likely to happen because of the decline in mortality after stroke and ageing of populations ${ }^{16}$. PSD includes all types of dementias that happen after stroke, irrespective of their cause ${ }^{13}$. In prevalence studies, PSD included both pre-existing dementia and newonset dementia after stroke ${ }^{3}$. In community-based studies with adjustment for age, the prevalence of dementia in people with a history of stroke is about $30 \%{ }^{17}$. In hospital-based studies, the prevalence of PSD ranges from 5.9 to $32 \%{ }^{13}$. Stroke increases the risk of dementia up to 12 times ${ }^{18,19}$. The overall prevalence of dementia is estimated in India was $3.36 \% 20$.

In Bangladesh there is no research and data about prevalence or incidence of post stroke dementia. Post stroke dementia is the most disabling of all the neurological diseases and in the context of our country it poses a huge burden both socially and economically. The treatment cost benefit is frustrating and rehabilitation is not expectedly available. So, we should concentrate more on prevention. As there is no local data on this topic, this study is therefore planned to identify the association of dementia with ischemic stroke and to find out the determinants of dementia in ischemic stroke.

\section{Methods:}

This study was a case control study, which was carried out in the department of Neurology at BSMMU, Dhaka, from 1st January 2010 to 31st December 2011 for a duration of two years. The target population for this study included all patients presented with ischemic stroke of 40-70 years of age in both sexes. Age and sex matched volunteer/ patients other than ischemic stroke were selected as the control group. Data collection was conducted 
by researcher himself. All data were compiled and edited meticulously by thorough checking and rechecking. All omissions and inconsistencies were corrected and were removed methodically. All data were recorded systematically in preformed data collection form (questionnaire) and quantitative data was expressed as mean and standard deviation and qualitative data was expressed as frequency distribution and percentage. Statistical analysis was performed by using SPSS for windows version 15.0. $95 \%$ confidence limit was taken. Probability value $<0.05$ was considered as level of significance.

\section{Results and Observations:}

A total number of 120 respondents were included in this study of which 60 patients of ischemic stroke were selected as case and the rest 60 volunteer were selected as control.

The mean age of case and control group were 57.13 \pm 7.39 and $57.37 \pm 7.94$ respectively $(p=0.868)$. In both case and control groups male and female were equal in number which were $42(70.0 \%)$ and $18(30.0 \%)$ respectively. Smokers/ ex-smokers were more in case than control group which was $39(65.0 \%)$ and $15(25.0 \%)$ respectively $(p=0.001)$ with as OR of 5.57 with a $95 \% \mathrm{Cl}$ of $2.53-12.27$.
Non-smokers were more in case than control group which was $21(35.0 \%)$ and $45(75.0 \%)$ respectively. Diabetes mellitus was more common in case group than control which was $30(50.0 \%)$ and $5(8.3 \%)$ respectively. The difference was statistically significant $(p=0.001)$ with 11.00 as OR and $95 \% \mathrm{Cl}$ of 3.87-31.31. Hypertension was more common in case group than control which was $45(75.0 \%$ ) and $20(33.3 \%)$ respectively. The difference was statistically significant $(p=0.001)$ with 6.84 as OR and $95 \% \mathrm{Cl}$ of 2.71-13.27. Dyslipidaemia was more common in case group than control which was $39(65.0 \%)$ and $26(43.3 \%)$ respectively. The difference was statistically significant $(p=0.017)$ with 2.43 as OR and $95 \% \mathrm{Cl}$ of $1.16-5.07$. Cardiac diseases were more common in control group than case which was $5(8.3 \%)$ and $4(6.7 \%)$ respectively. The difference was statistically not significant $(p=0.729)$ with 0.79 as OR and $95 \% \mathrm{Cl}$ of 0.20 3.08. Family history of dementia was more common in case group than control which was $6(10.0 \%)$ and $1(1.7 \%)$ respectively. The difference was statistically not significant $(p=0.051)$ with 6.56 as OR and $95 \% \mathrm{Cl}$ of $0.76-56.22$. These are shown in Table I.

Table-I

Respondents characteristics $(n=120)$

\begin{tabular}{lcccc}
\hline Variables & \multicolumn{2}{c}{ Group } & P value & OR (95\%Cl) \\
\cline { 2 - 3 } & $\begin{array}{c}\text { Case (Stroke) } \\
\mathrm{n}=60\end{array}$ & $\begin{array}{c}\text { Control } \\
\text { (non-stroke) } \mathrm{n}=60\end{array}$ & & \\
\hline Age (y) & $57.13 \pm 7.39$ & $57.37 \pm 7.94$ & 0.868 & \\
Sex & & & & \\
Male & $42(70.0)^{\#}$ & $42(70.0)$ & 1.000 & \\
Female & $18(30.0)$ & $18(30.0)$ & & \\
Smoking & & & & \\
Smoker/Ex-smoker & $39(65.0)^{\#}$ & $15(25.0)$ & $0.001^{*}$ & $5.57(2.53-12.27)$ \\
Non smoker & $21(35.0)$ & $45(75.0)$ & & \\
Diabetes mellitus & $30(50.0)$ & $5(8.3)$ & $0.001^{*}$ & $11.00(3.87-31.31)$ \\
Hypertension & $45(75.0)$ & $20(33.3)$ & $0.001^{*}$ & $6.00(2.71-13.27)$ \\
Dyslipidaemia & $39(65.0)$ & $26(43.3)$ & 0.017 & $2.43(1.16-5.07)$ \\
Cardiac disease & $4(6.7)$ & $5(8.3)$ & 0.729 & $0.79(0.20-3.08)$ \\
Family history ofdementia & $6(10.0)$ & $1(1.7)$ & 0.051 & $6.56(0.76-56.22)$ \\
\hline
\end{tabular}

${ }^{*}$ Chi-square test was done to measure the level of significance.

\#Figure within parentheses indicates in percentage. 
Table-II

Distribution of the respondents by dementia $(n=120)$

\begin{tabular}{|c|c|c|c|}
\hline \multirow[t]{2}{*}{ Dementia } & \multicolumn{2}{|c|}{ Group } & \multirow[t]{2}{*}{$p$ value } \\
\hline & Case $(n=60)$ & Control $(n=60)$ & \\
\hline Present & $18(30.0)$ & $2(3.3)$ & 0.001 \\
\hline Absent & $42(70.0)$ & $58(96.7)$ & \\
\hline Total & $60(100.0)$ & $60(100.0)$ & \\
\hline
\end{tabular}

${ }^{*}$ Chi-square test was done to measure the level of significance.

\#Figure within parentheses indicates in percentage.

Table-III

Distribution of the respondents by MMSE $(n=120)$

\begin{tabular}{lccccccc}
\hline MMSE & \multicolumn{3}{c}{ Case $(\mathrm{n}=60)$} & & \multicolumn{3}{c}{ Control $(\mathrm{n}=60)$} \\
\cline { 2 - 3 } & Dementia & Non-dementia & p value & & Dementia & Non-dementia & p value \\
\hline Severe & $01(5.55 \%)$ & $0(0.0)$ & & 00 & 00 & \\
Moderate & $14(77.77)^{\#}$ & $0(0.0)$ & 0.001 & & $1(50.0)$ & $0(0.0)$ & \\
Mild & $3(16.68)$ & $0(0.0)$ & & & $1(50.0)$ & $0(0.0)$ & \\
Normal & $0(0.0)$ & $42(100.0)$ & & $0(0.0)$ & $58(100.0)$ & \\
Total & $18(100.0)$ & $42(100.0)$ & & $2(100.0)$ & $58(100.0)$ & \\
\hline
\end{tabular}

${ }^{*}$ Chi-square test was done to measure the level of significance.

\#Figure within parentheses indicates in percentage.

(Scores on the MMSE ranges from 0 to 30 , with scores of 24 or higher being traditionally considered normal. Scores less than 10 generally indicate severe impairment while scores between 10 and 19 indicate moderate dementia. Scores between 19-24 indicate $\mathrm{MCl}$.)

Table II shows the distribution of the patients by dementia. In case and control group dementia was present in $18(30.0 \%)$ cases and $2(3.3 \%)$ in control respectively. Dementia was absent in $42(70.0 \%)$ cases and $58(96.7 \%)$ in control. The difference is statistically significant $(p=0.001)$.

Table III shows the distribution of the patients by MMSE. In case group dementia was present with a severe, moderate and mild MMSE in 01(5.55\%), 14 $(77.77 \%)$ and $3(16.68 \%)$ cases respectively. In control group dementia was present with moderate and mild MMSE in only $1(50.0 \%)$ case in each category.

Table-IV

Distribution of the respondents by smoking habit.

\begin{tabular}{lccc}
\hline Smoking habit & \multicolumn{2}{c}{ Group } & p value \\
\cline { 2 - 3 } & Case $(n=18)$ & Control $(n=02)$ & \\
\hline Smoker & $14(77.8) \#$ & $0(0.0)$ & 0.023 \\
Non-smoker & $4(22.2)$ & $2(100.0)$ & \\
Total & $18(100.0)$ & $2(100.0)$ & \\
\hline
\end{tabular}

${ }^{*}$ Chi-square test was done to measure the level of significance.

\#Figure within parentheses indicates in percentage.
Table IV shows the distribution of the patients by smoking habit. In case group smoker and nonsmoker were $14(77.8 \%)$ and $4(22.2 \%)$ respectively. In control group no smoker was found and only $2(100.0 \%)$ cases were non-smokers. The difference is statistically significant $(p=0.023)$.

\section{Table-V}

Distribution of the respondents by Hypertension.

\begin{tabular}{lccc}
\hline Hypertension & \multicolumn{2}{c}{ Group } & p value \\
\cline { 2 - 3 } & Case $(n=18)$ & Control $(n=2)$ & \\
\hline Present & $14(77.8)$ & $0(0.0)$ & 0.023 \\
Absent & $4(22.2)$ & $2(100.0)$ & \\
\hline Total & $18(100.0)$ & $2(100.0)$ & \\
\hline
\end{tabular}

${ }^{*}$ Chi-square test was done to measure the level of significance.

\#Figure within parentheses indicates in percentage.

Table $V$ shows the distribution of the patients by hypertension. In case group hypertension was present in $14(77.8 \%)$ cases and absent in $4(22.2 \%)$ cases. In control group hypertension was absent in all $2(100.0 \%)$ cases. The difference is statistically significant $(p=0.023)$. 
Table-VI

Distribution of the respondents by Diabetes mellitus.

\begin{tabular}{lccc}
\hline Diabetes & \multicolumn{2}{c}{ Group } & p value \\
\cline { 2 - 3 } & $\begin{array}{c}\text { Case } \\
(\mathrm{n}=18)\end{array}$ & $\begin{array}{c}\text { Control } \\
(\mathrm{n}=2)\end{array}$ & \\
\hline Present & $13(72.2)^{\#}$ & $0(0.0)$ & 0.042 \\
Absent & $5(27.8)$ & $2(100.0)$ & \\
\hline Total & $18(100.0)$ & $2(100.0)$ & \\
\hline
\end{tabular}

${ }^{*}$ Chi-square test was done to measure the level of significance. \#Figure within parentheses indicates in percentage.

Table VI shows the distribution of the patients with dementia by diabetes mellitus. In case group diabetes mellitus was present in $13(72.2 \%)$ cases and absent in $5(27.8 \%)$ cases. In control group diabetes mellitus was absent in all $2(100.0 \%)$ cases. The difference is statistically significant $(p=0.042)$.

Table-VII

Distribution of the respondents by dyslipidaemia.

\begin{tabular}{lccc}
\hline Dyslipidaemia & \multicolumn{2}{c}{ Group } & p value \\
\cline { 2 - 3 } & $\begin{array}{c}\text { Case } \\
(n=18)\end{array}$ & $\begin{array}{c}\text { Control } \\
(n=02)\end{array}$ & \\
\hline Present & $13(72.2)^{\#}$ & $0(0.0)$ & 0.042 \\
Absent & $5(27.8)$ & $2(100.0)$ & \\
\hline Total & $18(100.0)$ & $2(100.0)$ & \\
\hline
\end{tabular}

${ }^{*}$ Chi-square test was done to measure the level of significance. \#Figure within parentheses indicates in percentage.

Table VII shows the distribution of the patients by dyslipidaemia. In case group dyslipidaemia was present in $13(72.2 \%)$ cases and absent in $5(27.8 \%)$ cases. In control group dyslipidaemia was absent in all $2(100.0 \%)$ cases. The difference is statistically significant $(p=0.042)$.

\section{Table-VIII}

Distribution of the respondents by Cardiac disease

\begin{tabular}{lccc}
\hline Cardiac & \multicolumn{2}{c}{ Group } & pvalue \\
\cline { 2 - 3 } disease & $\begin{array}{c}\text { Case } \\
(\mathrm{n}=18)\end{array}$ & $\begin{array}{c}\text { Control } \\
(\mathrm{n}=02)\end{array}$ & \\
\hline Present & $1(5.6)^{\#}$ & $1(50.0)$ & 0.047 \\
Absent & $17(94.4)$ & $1(50.0)$ & \\
\hline Total & $18(100.0)$ & $2(100.0)$ & \\
\hline
\end{tabular}

${ }^{*}$ Chi-square test was done to measure the level of significance. \#Figure within parentheses indicates in percentage.
Table VIII shows the distribution of the patients by cardiac disease. In case group cardiac disease was present in $1(5.6 \%)$ case and absent in 17 (94.4\%) cases. In control group cardiac disease was present only $1(50.0 \%)$ case and absent in only $1(50.0 \%)$ case. The difference is statistically significant $(p=0.047)$.

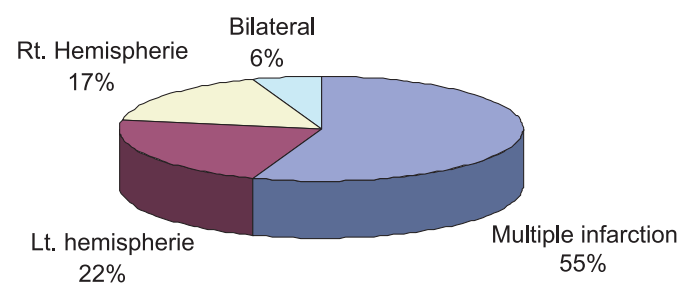

Fig.-3: Distribution of respondents by CT/ MRI findings

Figure 3 shows distribution of patients according to site of lesion by CT/MRI scan where multiple infraction in $10(55 \%)$, left hemispheric $4(22 \%)$, right hemispheric $3(17 \%)$ and bilateral $1(6 \%)$ were found.

Table-IX

Distribution of the respondents by family history of dementia.

\begin{tabular}{lccc}
\hline $\begin{array}{l}\text { Family history } \\
\text { of dementia }\end{array}$ & \multicolumn{2}{c}{ Group } & p value \\
\cline { 2 - 3 } & $\begin{array}{c}\text { Case } \\
(n=18)\end{array}$ & $\begin{array}{c}\text { Control } \\
(\mathrm{n}=02)\end{array}$ & \\
\hline Yes & $4(22.2)^{\#}$ & $0(0.0)$ & 0.456 \\
No & $14(77.8)$ & $2(100.0)$ & \\
\hline Total & $18(100.0)$ & $2(100.0)$ & \\
\hline
\end{tabular}

${ }^{*}$ Chi-square test was done to measure the level of significance. \#Figure within parentheses indicates in percentage.

Table IX shows the distribution of the patients by family history of dementia. In case group family history of dementia was present in $4(22.2 \%)$ cases and absent in 14 (77.8\%) cases. In control group no family history of dementia was found and absent in $2(100.0 \%)$ cases. The difference is not statistically significant $(p=0.456)$. 
Table-X

Distribution of the respondents by biochemical parameters $(n=120)$

\begin{tabular}{|c|c|c|c|}
\hline \multirow{2}{*}{$\begin{array}{l}\text { Biochemical } \\
\text { parameters }\end{array}$} & \multicolumn{2}{|c|}{ Group } & \multirow[b]{2}{*}{$p$ value } \\
\hline & $\begin{array}{c}\text { Case } \\
(\text { Mean } \pm S D)\end{array}$ & $\begin{array}{c}\text { Control } \\
\text { (Mean } \pm S D)\end{array}$ & \\
\hline $\begin{array}{l}\text { Blood Sugar } \\
\text { (Random) }\end{array}$ & $6.45 \pm 2.34$ & $6.15 \pm 1.48$ & 0.866 \\
\hline $\begin{array}{l}\text { Serum } \\
\text { creatinine }\end{array}$ & $1.18 \pm 0.44$ & $0.88 \pm 0.02$ & 0.381 \\
\hline S. TSH & $2.24 \pm 1.31$ & $2.92 \pm 1.19$ & 0.496 \\
\hline Vitamin $B_{12}$ & $665.07 \pm 277.55$ & $796.50 \pm 112.43$ & 0.121 \\
\hline
\end{tabular}

*t test was done to measure the level of significance.

Table $X$ shows the distribution of the patients by biochemica1l parameters. In case and control groups the mean blood sugar was $6.45 \pm 2.34$ and $6.15 \pm 1.48$ respectively $(p=0.866)$. In case and control groups the mean serum creatinine was 1.18 \pm 0.44 and $0.88 \pm 0.02 \mathrm{mg}$ respectively $(p=0.381)$. In case and control groups the mean $\mathrm{S}$. TSH was $2.24 \pm 1.31$ and $2.92 \pm 1.19 \mathrm{mmol} / \mathrm{L}$ respectively $(p=0.496)$. In case and control groups the mean vitamin $B_{12}$ was $665.07 \pm 277.55$ and $796.50 \pm$ 112.43 respectively $(p=0.121)$.

Table-XI

Distribution of the respondents by serum lipid profile $(n=120)$

\begin{tabular}{lccc}
\hline $\begin{array}{l}\text { Serum lipid } \\
\text { profile }\end{array}$ & $\begin{array}{c}c \\
\text { Gase } \\
\text { (Mean } \pm \text { SD) }\end{array}$ & $\begin{array}{c}\text { Control } \\
(\text { Mean } \pm \text { SD) }\end{array}$ & p value \\
\hline $\begin{array}{l}\text { Total } \\
\text { cholesterol }\end{array}$ & $198.59 \pm 64.45$ & $182.00 \pm 7.07$ & .727 \\
LDL & $126.53 \pm 52.09$ & $109.50 \pm 3.53$ & .658 \\
HDL & $39.47 \pm 12.56$ & $53.50 \pm 4.95$ & .144 \\
TG & $149.41 \pm 77.82$ & $96.00 \pm 43.84$ & .362 \\
\hline
\end{tabular}

${ }^{*} t$ test was done to measure the level of significance.

Table XI shows the distribution of the patients by serum lipid profile. In case and control groups the mean Total cholesterol was $198.59 \pm 64.45$ and $182.00 \pm 7.07 \mathrm{mg} / \mathrm{L}$ respectively $(p=0.727)$. In case and control groups the mean LDL was $126.53 \pm 52.09$ and $109.50 \pm 3.53 \mathrm{mg} / \mathrm{L}$ respectively $(p=0.658)$. In case and control groups the HDL was $39.47 \pm 12.56$ and $53.50 \pm 4.95 \mathrm{mg} / \mathrm{L}$ respectively $(\mathrm{p}=0.144)$. In case and control groups the mean TG was $149.41 \pm 77.82$ and $96.00 \pm 43.84 \mathrm{mg} / \mathrm{L}$ respectively $(\mathrm{p}=0.362)$.

Table-XII

Distribution of the respondents by dementia and age

\begin{tabular}{lccc}
\hline Age & \multicolumn{2}{c}{ Group } & pvalue* $^{*}$ \\
\cline { 2 - 4 } & $\begin{array}{c}\text { Dementia } \\
(\mathrm{n}=20)\end{array}$ & $\begin{array}{c}\text { No dementia } \\
(\mathrm{n}=100)\end{array}$ & \\
\hline Mean $( \pm S D)$ & $61( \pm 7.62)$ & $56.4( \pm 7.4)$ & 0.007 \\
\hline *Unpaired t test was done to measure the level of significance
\end{tabular}

Table XII shows the distribution of the respondents by dementia and age. Out of all patients of dementia mean of age was $61( \pm 7.62)$ years. On the contrary among all respondents of non-dementia, mean of age was $56.4( \pm 7.4)$ years. This variation is statistically significant at $p$ value less than 0.007 level.

Table-XIII

Distribution of the respondents by dementia and stroke $(n=120)$

\begin{tabular}{lccc}
\hline Respondents & \multicolumn{2}{c}{ Group } & pvalue $^{*}$ \\
\cline { 2 - 3 } & $\begin{array}{c}\text { Dementia } \\
(\mathrm{n}=20)\end{array}$ & $\begin{array}{c}\text { No dementia } \\
(\mathrm{n}=100)\end{array}$ & \\
\hline $\begin{array}{l}\text { Case } \\
\text { (stroke) }\end{array}$ & $18(90.0)$ & $42(42.0)$ & \\
$\begin{array}{l}\text { Control } \\
\text { (Healthy }\end{array}$ & $2(10.0)$ & $58(58.0)$ & $<0.001$ \\
adult) & & & \\
\hline Total & $20(100.0)$ & $100(100.0)$ & \\
\hline
\end{tabular}

${ }^{*} \mathrm{Chi}$ square test was done to measure the level of significance OR $(95 \% \mathrm{Cl})=12.43(2.74-56.48)$

Table XIII shows the distribution of the respondents by dementia. Out of all patients of ischemic stroke 18 had developed dementia. On the contrary among healthy control only 2 had dementia. This variation is statistically highly significant at $p$ value less than 0.001 level. Patients with stroke had 12.43 times more chance to develop dementia than healthy controls. 
Table-XIV

Distribution of the respondents by dementia and smoking $(n=120)$

\begin{tabular}{lccc}
\hline Smoking & \multicolumn{2}{c}{ Group } & pvalue* $^{*}$ \\
\cline { 2 - 3 } & $\begin{array}{c}\text { Dementia } \\
(\mathrm{n}=20)\end{array}$ & $\begin{array}{c}\text { No dementia } \\
(\mathrm{n}=100)\end{array}$ & \\
\hline Present & $14(70.0)$ & $40(40.0)$ & \\
Absent & $6(30.0)$ & $60(60.0)$ & 0.014 \\
\hline Total & $20(100.0)$ & $100(100.0)$ & \\
\hline
\end{tabular}

${ }^{*}$ Chi square test was done to measure the level of significance OR $(95 \% \mathrm{Cl})=3.5(1.24-9.87)$

Table XIV shows the distribution of the respondents by dementia and smoking habit. Out of all patients of dementia $70.0 \%$ were smoker. On the contrary among all respondents of non-dementia $40.0 \%$ were smoker. This variation is statistically significant at $p$ value less than 0.014 level. Smokers had 3.5 times more chance to develop dementia than that of non-smoker.

Table-XV

Distribution of the respondents by dementia and hypertension $(n=120)$

\begin{tabular}{lccc}
\hline Hypertension & \multicolumn{2}{c}{ Group } & pvalue $^{*}$ \\
\cline { 2 - 3 } & $\begin{array}{c}\text { Dementia } \\
(\mathrm{n}=20)\end{array}$ & $\begin{array}{c}\text { No dementia } \\
(\mathrm{n}=100)\end{array}$ & \\
\hline Present & $14(70.0)$ & $51(51.0)$ & \\
Absent & $6(30.0)$ & $49(49.0)$ & $<0.12$ \\
\hline Total & $20(100.0)$ & $100(100.0)$ & \\
\hline
\end{tabular}

${ }^{*}$ Chi square test was done to measure the level of significance

Table XV shows the distribution of the respondents by dementia and hypertension. Out of all patients of dementia $70 \%$ were hypertensive. On the contrary among all respondents of non-dementia $51 \%$ were hypertensive. This variation is statistically not significant at $p$ value less than 0.012 level.

\section{Table-XVI}

Distribution of the respondents by dementia and diabetes mellitus $(n=120)$

\begin{tabular}{lccc}
\hline DM & \multicolumn{2}{c}{ Group } & pvalue $^{*}$ \\
\cline { 2 - 3 } & $\begin{array}{c}\text { Dementia } \\
(\mathrm{n}=20)\end{array}$ & $\begin{array}{c}\text { No dementia } \\
(\mathrm{n}=100)\end{array}$ & \\
\hline Present & $13(65.0)$ & $22(22.0)$ & \\
Absent & $7(35.0)$ & $78(78.0)$ & $<0.001$ \\
\hline Total & $20(100.0)$ & $100(100.0)$ & \\
\hline
\end{tabular}

${ }^{*}$ Chi square test was done to measure the level of significance OR $(95 \% \mathrm{Cl})=6.58(2.34-18.51)$
Table XVI shows the distribution of the respondents by dementia and diabetes mellitus. Out of all patients of dementia $65 \%$ were diabetic. On the contrary among all respondents of non-dementia $35 \%$ were non diabetic. This variation is statistically significant at $p$ value less than 0.001 level. Diabetic patients had 6.58 times more chance to develop dementia than that of non-diabetic patients.

\section{Table-XVII}

Distribution of the respondents by dementia and dyslipidaemia $(n=120)$

\begin{tabular}{lccr}
\hline Dyslipidaemia & \multicolumn{2}{c}{ Group } & pvalue $^{*}$ \\
\cline { 2 - 3 } & $\begin{array}{c}\text { Dementia } \\
(\mathrm{n}=20)\end{array}$ & $\begin{array}{c}\text { No dementia } \\
(\mathrm{n}=100)\end{array}$ & \\
\hline Present & $13(65.0)$ & $52(52.0)$ & \\
Absent & $7(35.0)$ & $48(48.0)$ & $<0.287$ \\
\hline Total & $20(100.0)$ & $100(100.0)$ & \\
\hline${ }^{*}$ Chi square test was done to measure the level of significance
\end{tabular}

Table XVII shows the distribution of the respondents by dementia and dyslipidaemia. Out of all patients of dementia $65 \%$ had dyslipidaemia. On the contrary among all respondents of non-dementia $52 \%$ had dyslipidaemia. This variation is statistically not significant at $p$ value less than 0.287 level.

\section{Table-XVIII}

Distribution of the respondents by dementia and family history of dementia $(n=120)$

\begin{tabular}{lccc}
\hline $\begin{array}{l}\text { Family } \\
\text { history of } \\
\text { dementia }\end{array}$ & $\begin{array}{c}\text { Dementia } \\
(\mathrm{n}=20)\end{array}$ & $\begin{array}{c}\text { No dementia } \\
(\mathrm{n}=100)\end{array}$ & pvalue $^{*}$ \\
\hline Present & $\begin{array}{c}4(20.0) \\
4(4.0)\end{array}$ & \\
Absent & $16(80.0)$ & $96(96.0)$ & 0.033 \\
\hline Total & $20(100.0)$ & $100(100.0)$ & \\
\hline
\end{tabular}

${ }^{*}$ Chi square (after Yates correction) test was done to measure the level of significance

OR $(95 \% \mathrm{Cl})=6.00(1.36-26.45)$

Table XVIII shows the distribution of the respondents by dementia and family history of dementia. Out of all patients of dementia $20 \%$ had family history of dementia. On the contrary among all respondents of non-dementia $4 \%$ had family history of dementia. This variation is statistically significant at $p$ value less than 0.033 level. Family history of dementia had 6 times more chance to develop dementia than that of no family history of dementia. 
Table-XIX

Distribution of the respondents by dementia and different risk factors $(n=120)$

\begin{tabular}{|c|c|c|c|c|}
\hline \multirow[t]{2}{*}{ Variables } & \multicolumn{2}{|c|}{ Group } & \multirow[t]{2}{*}{ Unadjusted OR } & \multirow[t]{2}{*}{ Adjusted OR } \\
\hline & $\begin{array}{l}\text { Dementia } \\
(n=20)\end{array}$ & $\begin{array}{c}\text { No dementia } \\
(n=100)\end{array}$ & & \\
\hline Stroke & $18(90.0)$ & $42(42.0)$ & 12.43 & $8.49^{* *}(1.42-50.64)$ \\
\hline Smoker & $14(70.0)$ & $40(40.0)$ & 3.5 & $1.28(0.35-4.68)$ \\
\hline DM & $13(65.0)$ & $22(22.0)$ & 6.58 & $4.91^{* *}(1.35-17.82)$ \\
\hline Family history of dementia & $4(20.0)$ & $4(4.0)$ & 6.0 & $2.3(0.42-12.62)$ \\
\hline Age $(y)$ & $61( \pm 7.62)$ & $56.4( \pm 7.4)$ & & $1.14^{* *}(1.04-1.25)$ \\
\hline
\end{tabular}

*Significant

Table XIX shows in bivariate analysis we got ischemic stroke, smoking habit, diabetes mellitus, family history of dementia and age as significant risk factors for dementia. In binary logistic regression model we entered these variables as predictors for dementia to draw the conclusion about the significant risk factors for dementia. In this logistic model (enter method) we found ischemic stroke, diabetes mellitus and age as significant risk factors for dementia. Since age is a quantitative variable, an increase in one-year in age has a $14 \%(95 \% \mathrm{Cl}$ $4 \%-25 \%)$ increase in odds of having dementia. This $14 \%$ obtained by taking Odd of age-15. Discussion:

A total number of 120 respondents were included in this study of which 60 patients of ischemic stroke were selected as case and the rest 60 volunteers were selected as control.

The distribution of the patients by age was recorded in this study. In $40-49$ years age group among cases dementia was present in $2(11.1 \%)$ cases and absent in control group. In $50-59$ years age group dementia was present in $5(27.8 \%)$ cases and absent in control group. In 60 years and above age group dementia was present in $11(61.1 \%)$ cases and $2(100.0 \%)$ in control group. The mean age \pm SD is $60.50 \pm 7.44$ and $70.00 \pm 0.0$ in case and control groups respectively $(p=0.021)$. Similar result was recorded by Lis and Gaviria ${ }^{21}$.

The distribution of the patients by sex was recorded in this study. In case group the presence of dimentia in male was predominant than female which was $13(72.2 \%)$ and $5(27.8 \%)$ respectively. In control group the presence of dimentia in male was 2
$(100.0 \%)$ and no in female. The difference was statistically not significant $(p=0.346)$. But the study done by Andersen et al (1999) mentioned that there was a gender differences in risk for vascular dementia. Similarly Launer et al $(1999)^{22}$ found that gender was a potential modifiers of risk of dementia which is consistent with the present study.

The distribution of the patients by presences of dementia was recorded. In case and control group dementia was present in $18(30.0 \%)$ cases and $2(3.3 \%)$ in controls respectively. Dementia was absent in case and control groups which was $42(70.0 \%)$ in cases and $58(96.7 \%)$ in controls respectively. The difference was statistically significant $(p=0.001)$. Tatemichi et al $(1992)^{19}$ shows the frequency of dementia with acute ischemic stroke, based on examinations performed 3 months after stroke onset. They found dementia was present $26.3 \%$ in cases and $3.2 \%$ in controls. So, this study permit to conclude that dementia was directly associated with ischemic stroke.

The distribution of the patients by smoking habit is recorded in this study. In case group smoker and non-smoker were $14(77.8 \%)$ and $4(22.2 \%)$ respectively. In control group no smoker was found and only $2(100.0 \%)$ cases were non-smoker. The difference is statistically significant $(p=0.023)$. Smokers have 3.17 times more chance to develop stroke than non-smokers. Similar result was reported by Posner et al $(2000)^{23}$ and mentioned that smoking increased the risk of dementia significantly.

The distribution of the patients by MMSE is recorded in this study. In case group dementia was present 
with a severe, moderate and mild MMSE in $01(5.55 \%), 14(77.77 \%)$ and $3(16.68 \%)$ cases respectively. In control group dementia was present with a moderate and mild MMSE in only $1(50.0 \%)$ case in each category.

The distribution of the patients with dementia by hypertension was recorded in this study. In case group hypertension is present in $14(77.8 \%)$ cases and absent in $4(22.2 \%)$ cases. In control group hypertension was absent in all $2(100.0 \%)$ cases. The difference is statistically significant $(p=0.023)$. Posner et al $(2000)^{23}$ mentioned that hypertension is directly affect memory, language, or general cognitive function. A history of hypertension may be an antecedent to $\mathrm{VaD}$, particularly in the presence of heart disease or diabetes.

The distribution of the patients with dementia by diabetes mellitus was recorded in this study. In case group diabetes mellitus was present in $13(72.2 \%)$ cases and absent in 5(27.8\%) cases. In control group diabetes mellitus was absent in all $2(100.0 \%)$ cases. The difference is statistically significant $(p=0.042)$. Similar result was reported by Strachan et $\mathrm{al}^{26}$.

The distribution of the patients with dementia by dyslipidaemia was recorded in this study. In case group dyslipidaemia was present in $13(72.2 \%)$ cases and absent in $5(27.8 \%)$ cases. In control group dyslipidaemia was absent in all $2(100.0 \%)$ cases. The difference is statistically significant $(p=0.042)$.

The distribution of the patients with dementia by cardiac disease was recorded in this study. In case group cardiac disease was present in $1(5.6 \%)$ case and absent in 17 (94.4\%) cases. In control group cardiac disease was present $1(50.0 \%)$ case and absent in $1(50.0 \%)$ case. The difference is statistically significant $(p=0.047)$. Similar result was reported by Posner et al $(2000)^{23}$ and mentioned that a history of hypertension may be an antecedent to $\mathrm{VaD}$, particularly in the presence of heart disease.

The distribution of the patients by family history of dementia was recorded. In case group family history of dementia was present in $4(22.2 \%)$ cases and absent in $14(77.8 \%)$ cases. In control group no family history of dementia was found i.e. absent in all $2(100.0 \%)$ cases. The difference is not statistically significant $(p=0.456)$. But Huang et al $(2004)^{27}$ mentioned that a family history of dementia continue to influence the occurrence of dementia. Launer et al (1999) ${ }^{22}$ also reported a result correlating between family history of dementia and occurrence of dementia and found a result which is consistent with the present study.

\section{References:}

1. American Psychiatric Association. 'Diagnostic and Statistical Manual of Mental Disorders: DSM-IV, $4^{\text {th }}$ ed.' Washington, DC: American Psychiatric Association 1994,

2. Bradley WG, Daroff RB, Fenichel GM, Jankovic $J$, editors. 'Neurology in clinical practice. $5^{\text {th }}$ ed.' Philadelphia: Butterworth-Heinemann Elsevier 2008.

3. Ropper $\mathrm{AH}$, Brown $\mathrm{RH}$, editors. 'Adams and Victor's principles of neurology' $8^{\text {th }}$ ed. New York The MacGraw-Hill Companies 2005.

4. Fauci AS, Kasper DL, Longo DL, Braunwald E, Hauser SL, Jameson JL, et al, editors, 'Harrison's principles of internal medicine' $17^{\text {th }}$ ed. New York: The MacGraw-Hill Companies 2008.

5. Clarfield AM, 'The decreasing prevalence of reversible dementias: an updated metaanalysis' Arch Intern Med; 2003, 163:22192229.

6. Clarfield AM, 'The reversible dementias: do they reverse?' Ann Intern Med 1988;109:476-486.

7. Weytingh MD, Bossuyt PM, van Crevel $\mathrm{H}$, 'Reversible dementia: more than $10 \%$ or less than $1 \%$ ? A quantitative review' J Neurol; 1995, 242: 466-471.

8. Rojas-Fernandez $\mathrm{CH}$, Moorhouse P, 'Current concepts in vascular cognitive impairment and pharmacotherapeutic implications' Ann Pharmacother . 2009;43:1310-23

9. Skoog I, Nilsson L, Palmertz B, Andreasson LA, Svanborg A, 'A population-based study of dementia in 85-year-olds' N Engl J Med 1993; 328: 153-8. 
10. Pohjasvaara T, Erkinjuntti T, Yilkoski R, Hietanen M, Vataja R, Kaste M, 'Clinical determinants of poststroke dementia' Stroke1998;29:75-81.

11. Inzitari D, Carlo A, Pracucci G, Lamassa M, Vanni $P$, Romanelli M, 'Incidence and determinants of poststroke dementia as defined by an informant interview method in a hospital-based stroke registry' Stroke 1998; 29:2087-93.

12. Madureira S, Guerreiro M, Ferro JM, 'Dementia and cognitive impairment three month after stroke' Eur J Neurol 2001;8:621-27.

13. Leys $D$, Hénon $H$, Mackowiak-Cordoliani MA, FP, 'Poststroke dementia' Lancet Neurol 2005; 4: 752-59

14. Murray CJ, Lopez AD, 'Global mortality, disability, and the contribution of risk factors: Global Burden of Disease Study' Lancet 1997; 349: 1436-42

15. Hankey GJ, Warlow CP, 'Treatment and secondary prevention of stroke: evidence, costs, and effects on individuals and populations. Lancet' 1999, 354: 1457-63.

16. Rothwell PM, Coull AJ, Giles MF, 'Change in stroke incidence, mortality, case-fatality, severity, and risk factors in Oxfordshire' UK from 1981 to 2004: Oxford Vascular Study. Lancet 2004,363: 1925-33.

17. Zhu L, Fratiglioni L, Guo Z, Aguero-Torres H, Winblad B, Viitanen M, 'Association of stroke with dementia, cognitive impairment, and functional disability in the very old: a population based study' Stroke 1998; 29: 2094-99.

18. Liu CK, Lin RT, Chen YF, Tai CT, Yen YY, Howng SL, 'Prevalence of dementia in an urban area in Taiwan' J Formos Med Assoc 1996 ;95:762-68.

19. Tatemichi TK, Desomnd DW, Mayeux R, Paik $M$, Hier DB, Price TR, 'Dementia in stroke survivors in the Stroke Data Bank cohort prevalence, incidence, risks, and clinical features in a hospitalized cohort' Neurology 1992;42:1185-93.

20. Shaji S, Bose S and Verghese A, 'Prevalence of dementia in an urban population in Kerala, India' British Journal of Psychiatry 2005, 186:136-40.

21. Lis and Gaviria M. Vascular dementia, hypertension, and the brain. Neurol Res. 1997;19:471-80.

22. Launer LJ, Andersen K, Dewey ME, Letenneur L, Ott A, Amaducci LA, 'Rates and risk factors for dementia and Alzheimer's disease: results from EURODEM pooled analyses. EURODEM Incidence Research Group and Work Groups. European Studies of Dementia. Neurology'. 1999;52(1):78-84.

23. Posner HB, Tang MX, Luchsinger J, Lantigua $R$,Stern $Y$, Mayeux R, 'The relationship of hypertension in the elderly to $A D$, vascular dementia, and cognitive function' Neurology 2000;58: 1175-81

24. O'Bryant SE, Humphreys JD, Smith GE, Ivnik RJ, Graff-Radford NR, Petersen RC. 'Detecting Dementia with the Mini-Mental State Examination (MMSE) in Highly Educated Individuals' Arch Neurol. 2008 ; 65(7): 963-67

25. Strauss, E.; Sherman, EMS.; Spreen, O, 'A Compendium of Neuropsychological Tests: Administration, norms, and commentary' 3rd ed. Oxford University Press; Oxford: 2006.

26. Strachan MW, Deary IJ, Ewing FM, Frier BM, 'Is type II diabetes associated with an increased risk of cognitive dysfunction' A critical review of published studies. Diabetes Care; 1997, 20: 438-45

27. Huang W, Qiu C, von Strauss E, Winblad B, Fratiglioni L, 'APOE genotype, family history of dementia, and Alzheimer disease risk: a 6year follow-up study' Arch Neurol. 2004;61(12):1930-1934 